\title{
Comparison of Serum Total Valproic Acid Levels and \%CDT Values in Chronic Alcohol Addictive Patients in an Italian Clinic: A Retrospective Study
}

\author{
Vincenzo De Iuliis $^{1,2} \cdot$ Raimondo Gelormini $^{1} \cdot$ Mariarosaria Flacco $^{1}$ • \\ Giuseppe Moriello $^{1,2} \cdot$ Marika Caruso $^{1,2} \cdot$ Eugenia Barone $^{1,2} \cdot$ Maria Golato $^{1}$. \\ Elena Toniato $^{2} \cdot$ Pio Conti $^{3} \cdot$ Stefano Martinotti ${ }^{2,4}$
}

Published online: 11 January 2016

(C) The Author(s) 2016. This article is published with open access at Springerlink.com

\begin{abstract}
Background Valproate is a broad-spectrum anticonvulsant that is effective in the treatment of tonic-clonic, myoclonic and absence seizures as well as in partial seizures as a second-line drug. It has been widely demonstrated in the literature that the effect of valproate on typeA $\gamma$-aminobutyric acid (GABA-A) receptors may reduce relapse to ethanol abuse. This retrospective study evaluated a 3-year period in which 42 patients from the Department of Alcoholism and Substance Abuse (DASA) were treated with valproate.

Objectives We compared different serum total valproic acid (VPA) concentrations, and the effectiveness of this drug in maintaining alcohol abstinence was evaluated by percentage of carbohydrate deficient transferrin (\%CDT) values.

Method CDT is a biochemical marker used for identifying regular high alcohol consumption and monitoring
\end{abstract}

Stefano Martinotti

smartinotti@unich.it

Vincenzo De Iuliis

vincenzodeiuliis1985@gmail.com

Raimondo Gelormini

raimondogelormini@tin.it

Mariarosaria Flacco

mariarosariaflacco@hotmail.it

Giuseppe Moriello

giuseppe_moriello@alice.it

Marika Caruso

marikacaruso@hotmail.it

Eugenia Barone

eugenia_85@libero.it

Maria Golato

barfabr@libero.it abstinence in outpatients during treatment. Serum concentrations of valproate were divided into four groups: $<10,10-30,31-50$, and $>50 \mu \mathrm{g} / \mathrm{mL}$.

Results This study shows that a mean serum total VPA concentration $>30 \mu \mathrm{g} / \mathrm{mL}$ is more effective in maintaining alcohol abstinence than a lower one $(p<0.05)$. In this study, mean serum total VPA concentrations between 31 and $50 \mu \mathrm{g} / \mathrm{mL}$ showed the same effectiveness as higher ones $(>50 \mu \mathrm{g} / \mathrm{mL})$; in fact, there was no significant difference in mean \%CDT values between these two groups $(p>0.05)$. After at least 12 months' treatment with valproate, mean platelet counts increased by $12 \times 10^{3} / \mu \mathrm{L}$ compared with baseline $\left(254 \pm 63\right.$ vs $242 \times 10^{3} / \mu \mathrm{L}$, $p>0.05$, respectively) in patients with mean serum total VPA levels $<10 \mu \mathrm{g} / \mathrm{mL}$; increased by $8 \times 10^{3} / \mu \mathrm{L}$ from baseline $\left(253 \pm 59\right.$ vs $245 \times 10^{3} / \mu \mathrm{L}, p>0.05$, respectively) in patients with levels between 10 and $30 \mu \mathrm{g} / \mathrm{mL}$; decreased by $2 \times 10^{3} / \mu \mathrm{L}$ from baseline $(265 \pm 63$ vs

Elena Toniato

e.toniato@unich.it

Pio Conti

pconti@unich.it

1 Unit of Clinical Pathology, SS Annunziata University Hospital, ASL Lanciano-Vasto-Chieti, Via dei Vestini 31, Chieti, Italy

2 Department of Medical, Oral and Biotechnologic Sciences, Via dei Vestini 31, Chieti, Italy

3 Immunology Division, Postgraduate Medical School, University of Chieti, Viale Unità d'Italia 73, Chieti, Italy

4 Unit of Clinical Molecular Biology and Predictive Medicine, SS Annunziata University Hospital, University of Chieti, ASL Lanciano-Vasto-Chieti, Chieti, Italy 
$267 \times 10^{3} / \mu \mathrm{L}, p>0.05$, respectively) in patients with levels between 31 and $50 \mu \mathrm{g} / \mathrm{mL}$, and decreased by $48 \times 10^{3} / \mu \mathrm{L}$ from baseline $\left(215 \pm 56\right.$ vs $263 \times 10^{3} / \mu \mathrm{L}$, $p<0.05$, respectively) in patients with levels $>50 \mu \mathrm{g} / \mathrm{mL}$. Conclusion A mean serum total concentration lower than the currently accepted therapeutic level $(50-100 \mu \mathrm{g} / \mathrm{mL})$ may have the same effectiveness in maintaining alcohol abstinence with a lower risk of presenting side effects.

\section{Key Points}

Mean total serum valproic acid levels between 31 and $50 \mu \mathrm{g} / \mathrm{mL}$ appear to be as effective in maintaining alcohol abstinence as the currently accepted therapeutic range of $50-100 \mu \mathrm{g} / \mathrm{mL}$.

Patients with total serum valproic acid levels between 50 and $100 \mu \mathrm{g} / \mathrm{mL}$ had significantly reduced platelet counts compared with patients with serum total valproic acid levels $<30 \mu \mathrm{g} / \mathrm{mL}$.

\section{Introduction}

Valproate is a broad-spectrum anticonvulsant that is effective in the treatment of tonic-clonic, myoclonic, tonic and absence seizures and also in partial seizures as a second-line drug [1,2]. Valproate is currently the most frequently prescribed antiepileptic drug in the world [3]. It has been approved for the treatment of bipolar disorders and migraine [4-7], and is also administered as an anxiolytic compound [8-10]. The therapeutic mechanism of valproate is still unclear. Its pharmacological effects involve a variety of mechanisms including suppression of $N$-methyl-Daspartate (NMDA)-evoked transient depolarization in the rat neocortex in vitro [11]; blockade of voltage-gated sodium channels and modulation of dopaminergic and serotoninergic transmission [7]; and enhancement of typeA $\gamma$-aminobutyric acid (GABAA) receptor activation by increasing brain GABA levels. Furthermore, valproate activates the GABA-related, glutamic acid decarboxylase, and inhibits the GABA degradative enzymes GABA aminotransferase [12-14] and succinate semialdehyde dehydrogenase [15]. A study presented by Roy-Byrne et al. showed that some anticonvulsant drugs decrease ethanol withdrawal symptoms, and that anticonvulsant treatments may reduce the length of hospital stay for ethanol withdrawal [16]. In addition, it reduces the need for benzodiazepines in subgroups sensitive to benzodiazepine side effects, and enhances the efficacy of benzodiazepines when given in combination $[17,18]$. A Hammer and Brady study showed that valproate might be effective in the treatment of sedative-hypnotic withdrawal [19]. Moreover, the effect of valproate on GABAA receptors suggests that it may reduce relapse to ethanol and sedative use. Long-term GABAA receptor down-regulation in abstinent alcoholics and sedative abusers might explain ethanol and sedative craving and relapse. In fact, a case report from Brady et al. concerning ethanol relapse prevention suggests that valproate may reduce sedative-hypnotic relapse [20]. Thus, valproate, acting on GABA levels and GABAA receptor function, may have a role in the treatment of sedativehypnotic withdrawal and relapse prevention.

Carbohydrate-deficient transferrin (CDT) is a biochemical marker used for identifying recent, regular high alcohol consumption and for monitoring abstinence during outpatient treatment [21]. Transferrins are a class of singlechain, iron-binding glycoproteins, classified and named depending on the number of terminal sialic acid residues on the N-linked oligosaccharide chains (glycans), which may be biantennary, triantennary, or even tetraantennary in structure [22]. Under physiological conditions, the major transferring glycoform contains two disialylated biantennary glycans and was named tetrasialotransferrin. In alcoholics, ethanol and acetaldehyde suppresses the activity of glycosyl transferase and increases the activity of sialidase [23, 24]. Moreover, individuals who have been excessively drinking over the past 2 or more weeks typically show increased relative amounts of disialotransferrin and, in cases of a high disialotransferrin level, of asialotransferrin [25]. The calculation of these forms with respect to total transferrin is indicated as a percentage of CDT (\%CDT). $\%$ CDT showed a high sensitivity and specificity when compared with conventional markers of alcoholism such us GGT, AST, ALT and MCV [26, 27]. According to a comparative study by Legros et al. [28], we define 2.15 as the cut-off for these retrospective studies and for clinical diagnostic analysis in our laboratory.

In this retrospective study, we evaluated the effectiveness of valproate in maintaining alcohol abstinence based on \%CDT values. We also associated different levels of serum total valproic acid (VPA) concentrations in alcoholic patients with \%CDT values in order to identify the best treatment and drug response with minimal side effects.

\section{Methods}

This retrospective study evaluated a period of 3 years in which 42 patients (aged 29-64 years; $44.41 \pm 8.17$ ) from the Department of Alcoholism and Substance Abuse were treated with valproate. Patients treated with psychotropic drugs for psychiatric syndromes were excluded from the study. For each patient, three measurements of serum total 
VPA and \%CDT at monthly intervals were analyzed. Sampling time was in the morning prior to valproate consumption. Platelet counts were analyzed before starting valproate treatment and monthly during treatment for 3 consecutive months. Each patient was treated with valproate for at least 1 year at the time of analysis.

We stratified the patients into the following four groups based on mean serum total VPA concentrations; the group with the highest concentration $(>50 \mu \mathrm{g} / \mathrm{mL})$ corresponding to the maximum concentration $\left(C_{\max }\right)$ with area under the concentration-time curve from 0 to $24 \mathrm{~h}\left(\mathrm{AUC}_{(0-24 \mathrm{~h})}\right)$ of $850 \pm 150 \mu \mathrm{g} \times \mathrm{h} / \mathrm{mL}$ as reported by several pharmacokinetic studies [29]:

1. $<10 \mu \mathrm{g} / \mathrm{mL}$ corresponding to approximately $10 \%$ of $\mathrm{AUC}_{(0-24 \mathrm{~h})}$

2. $10-30 \mu \mathrm{g} / \mathrm{mL}$ corresponding to approximately $20 \%$ of $\mathrm{AUC}_{(0-24 \mathrm{~h})}$

3. $31-50 \mu \mathrm{g} / \mathrm{mL}$ corresponding to approximately $50 \%$ of $\mathrm{AUC}_{(0-24 \mathrm{~h})}$

4. $>50 \mu \mathrm{g} / \mathrm{mL}$ corresponding to $\mathrm{AUC}_{(0-24 \mathrm{~h})}$ and $C_{\max }$ $(45 \pm 10 \mu \mathrm{g} / \mathrm{mL})$

We compared the different serum concentrations of total VPA and the effectiveness in maintaining alcohol abstinence evaluated by \%CDT values. We evaluated baseline platelet count, ethanol consumption prior to VPA assumption and the number of patients with a mean \%CDT value $>2.15$ in each of the groups.

In order to compare valproate consumption with the mean \%CDT corresponding to each treatment group we applied computed statistical analysis to better define the application of significance.

For the statistical analysis, data are expressed as means \pm SEM. For evaluation of different parameters between the four groups, ANOVA followed by the appropriate post-hoc test was used.

In addition, we observed the number of cases in which the value of \%CDT was over the cut-off level (2.15\%). In this case, a chi-squared test for the statistical analysis was used. A $p$ value of $p<0.05$ was considered statistically significant.

Serum concentration of total VPA was evaluated by a Siemens Dimension EXL immunochemical method. \%CDT was measured by the HPLC method (Bio-Rad Variant Hplc).

We also excluded patients with genetic variants of transferrin, specifically $\mathrm{C}$ and $\mathrm{D}$ variants.

\section{Results}

Regarding the features of the study participants, there were no significant differences between the four groups in age, sex, baseline ethanol consumption or baseline platelet count (Table 1).

After at least 12 months' treatment with valproate, mean platelet counts increased by $12 \times 10^{3} / \mu \mathrm{L}$ compared with baseline $\left(254 \pm 63\right.$ vs $242 \times 10^{3} / \mu \mathrm{L}, p>0.05$, respectively) in patients with mean serum total VPA levels $<10 \mu \mathrm{g} / \mathrm{mL}$; increased by $8 \times 10^{3} / \mu \mathrm{L}$ from baseline $\left(253 \pm 59\right.$ vs $245 \times 10^{3} / \mu \mathrm{L}, p>0.05$, respectively) in patients with levels between 10 and $30 \mu \mathrm{g} / \mathrm{mL}$; decreased by $2 \times 10^{3} / \mu \mathrm{L}$ from baseline $\left(265 \pm 63\right.$ vs $267 \times 10^{3} / \mu \mathrm{L}$, $p>0.05$, respectively) in patients with levels between 31 and $50 \mu \mathrm{g} / \mathrm{mL}$; and decreased by $48 \times 10^{3} / \mu \mathrm{L}$ from baseline $\left(215 \pm 563\right.$ vs $263 \times 10^{3} / \mu \mathrm{L}, p<0.05$, respectively) in patients with levels $>50 \mu \mathrm{g} / \mathrm{mL}$.

Patients with mean serum total VPA levels $<10 \mu \mathrm{g} / \mathrm{mL}$ had a mean \%CDT of $1.86 \pm 0.94$, patients with levels between 10 and $30 \mu \mathrm{g} / \mathrm{mL}$ had a mean \%CDT of $2.08 \pm 1.46$, patients with levels between 31 and $50 \mu \mathrm{g} /$ $\mathrm{mL}$ had a mean \%CDT of $1.44 \pm 0.28$, patients with levels $>50 \mu \mathrm{g} / \mathrm{mL}$ had a mean \%CDT of $1.36 \pm 0.36$.

Mean \%CDT levels were significantly higher (indicating increased alcohol consumption) in patients with mean serum total VPA levels $<10 \mu \mathrm{g} / \mathrm{mL}$ compared with patients with levels between 31 and $50(p<0.05)$ or $>50 \mu \mathrm{g} / \mathrm{mL}$ $(p<0.05)$. Patients with mean serum total VPA levels

Table 1 Baseline characteristics of chronic alcohol-addicted patients in an Italian clinic stratified by mean serum total valproic acid concentration

\begin{tabular}{|c|c|c|c|c|c|}
\hline \multirow[t]{2}{*}{ Participant characteristics } & \multicolumn{5}{|c|}{ Mean valproic acid serum level } \\
\hline & $\begin{array}{l}<10 \mu \mathrm{g} / \mathrm{mL} \\
(n=10)\end{array}$ & $\begin{array}{l}10-30 \mu \mathrm{g} / \mathrm{mL} \\
(n=10)\end{array}$ & $\begin{array}{l}31-50 \mu \mathrm{g} / \mathrm{mL} \\
(n=11)\end{array}$ & $\begin{array}{l}>50 \mu \mathrm{g} / \mathrm{mL} \\
(n=11)\end{array}$ & ANOVA $p$ \\
\hline Age (years) & $42.77 \pm 4.34$ & $46.64 \pm 8.86$ & $40.84 \pm 9.29$ & $41.79 \pm 5.87$ & $>0.05$ \\
\hline $\operatorname{Sex}(M / F)$ & $7 / 3$ & $7 / 3$ & $8 / 3$ & $8 / 3$ & $>0.05$ \\
\hline $\begin{array}{l}\text { Ethanol consumption prior } \\
\text { to cessation (g/day) }\end{array}$ & $55.3 \pm 7.7$ & $53.2 \pm 7.4$ & $50.5 \pm 5.3$ & $54.6 \pm 6.5$ & $>0.05$ \\
\hline Baseline platelet count $\left(\times 10^{3} / \mu \mathrm{L}\right)$ & $242 \pm 62$ & $245 \pm 57$ & $267 \pm 60$ & $263 \pm 58$ & $>0.05$ \\
\hline
\end{tabular}


Fig. 1 Mean \%CDT values stratified by mean serum total valproic acid concentrations in chronic alcohol-addicted patients in an Italian clinic. Mean \%CDT levels were significantly higher in patients with mean serum total VPA levels $<10 \mu \mathrm{g} / \mathrm{mL}$ and between 10 and $30 \mu \mathrm{g} / \mathrm{mL}$ compared with values between 31 and 50 $(p<0.05)$ or $>50 \mu \mathrm{g} / \mathrm{mL}$ $(p<0.05)$, respectively. There was no significant difference in mean \%CDT between patients with mean serum total VPA levels between 31 and $50 \mu \mathrm{g} /$ $\mathrm{mL}$ and those with levels $>50 \mu \mathrm{g} / \mathrm{mL}$. $C D T$ carbohydrate-deficient transferrin

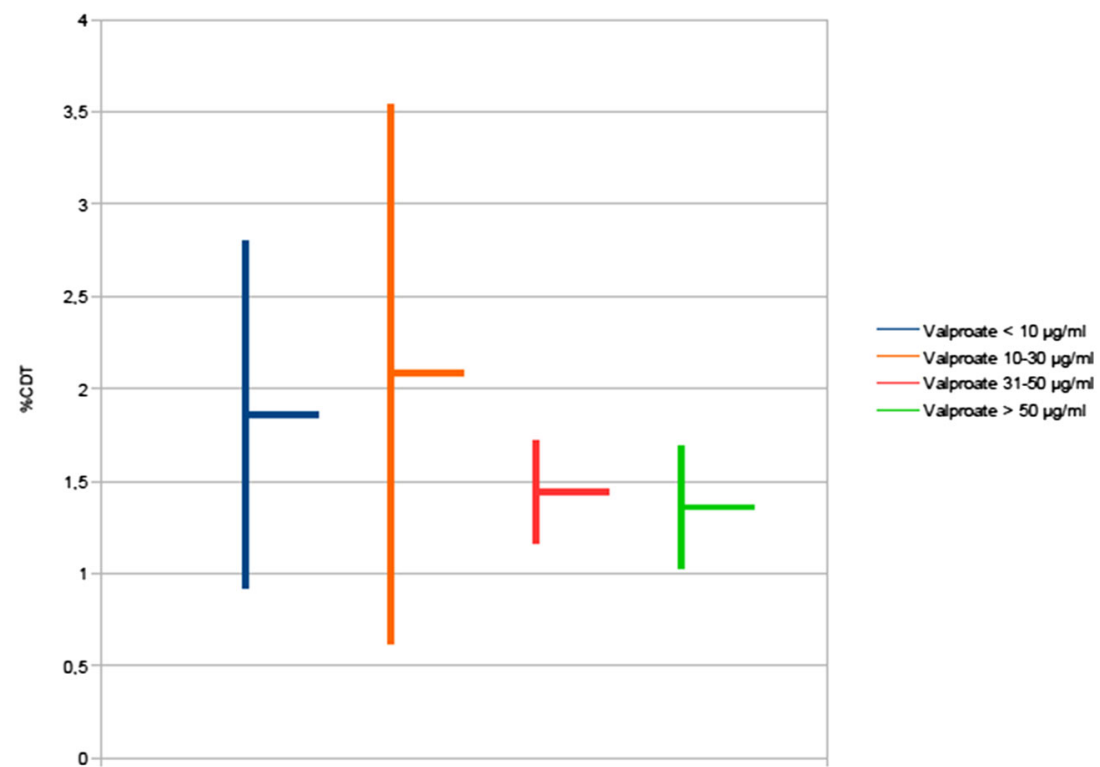

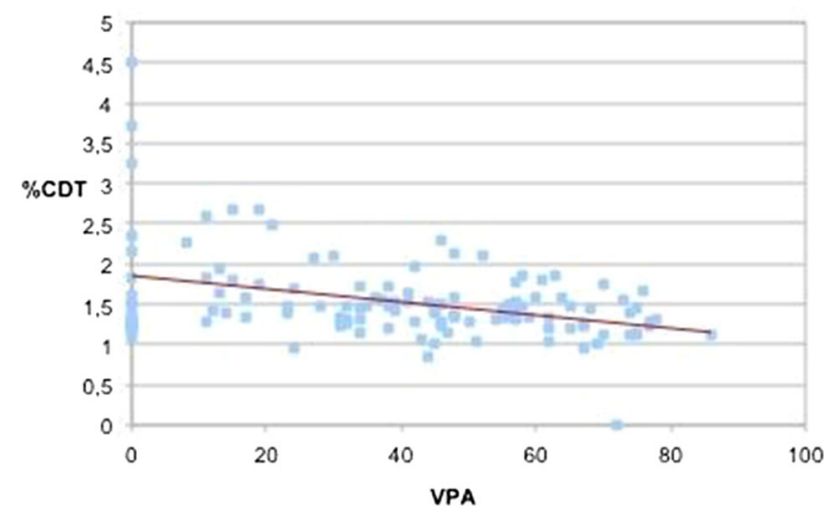

Fig. 2 Correlation between mean serum total valproic acid concentrations and \%CDT in chronic alcohol-addicted patients in an Italian clinic. Linear regression analysis showed an inverse relation between these two parameters $(r=-0.4)$. CDT carbohydrate-deficient transferrin, $V P A$ mean serum total valproic acid levels between 10 and $30 \mu \mathrm{g} / \mathrm{mL}$ also had significantly higher $\%$ CDT values when compared with patients with higher VPA levels ( $p<0.05$ vs $31-50 \mu \mathrm{g} / \mathrm{mL}$ and $>50 \mu \mathrm{g} / \mathrm{mL}$ ). However, there was no significant difference in mean $\%$ CDT values between patients with mean serum total VPA levels between 31 and $50 \mu \mathrm{g} / \mathrm{mL}$ and those with levels $>50 \mu \mathrm{g} / \mathrm{mL}$ (Fig. 1).

Linear regression analysis showed an inverse relation between total VPA concentration and \%CDT (Fig. 2, $r=-0.4)$. Thus, with increasing serum total VPA concentration, the \%CDT decreased.

Overall, this study shows 12 cases with \%CDT over the threshold $(\geq 2.15 \%)$, six cases with serum total VPA $<10 \mu \mathrm{g} / \mathrm{mL}(60 \%)$, five cases with serum total VPA between 10 and $30 \mu \mathrm{g} / \mathrm{mL}(50 \%)$, one case with a serum total VPA level between 31 and $50 \mu \mathrm{g} / \mathrm{mL}(9 \%)$ and no cases with serum total VPA levels $>50 \mu \mathrm{g} / \mathrm{mL}$ (Table 2).

Table 2 Serum total valproic acid concentrations of chronic alcoholic patients with $\%$ CDT values over $2.15 \%^{\mathrm{a}}$

\begin{tabular}{llll}
\hline Mean serum total valproic acid level & $\begin{array}{l}\text { Number of patients } \\
n(\%)\end{array}$ & $\begin{array}{l}\text { Patients with \%CDT }>2.15 \\
n(\%)\end{array}$ & $p$ value \\
\hline$<10 \mu \mathrm{g} / \mathrm{mL}$ & $10(24)$ & $6(60)$ & $\begin{array}{l}\mathrm{NS}(\mathrm{vs} 10-30 \mu \mathrm{g} / \mathrm{mL}) \\
<0.005(\mathrm{vs} 31-50 \mu \mathrm{g} / \mathrm{mL}) \\
\end{array}$ \\
& & & $<0.001(\mathrm{vs}>50 \mu \mathrm{g} / \mathrm{mL})$ \\
$10-30 \mu \mathrm{g} / \mathrm{mL}$ & $10(24)$ & $5(50)$ & $<0.05(\mathrm{vs} 31-50 \mu \mathrm{g} / \mathrm{mL})$ \\
$31-50 \mu \mathrm{g} / \mathrm{mL}$ & & $1(9)$ & $0.005(\mathrm{vs}>50 \mu \mathrm{g} / \mathrm{mL})$ \\
$>50 \mu \mathrm{g} / \mathrm{mL}$ & $11(26)$ & 0 & $\mathrm{NS}(\mathrm{vs}>50 \mu \mathrm{g} / \mathrm{mL})$ \\
Total & $11(26)$ & & Reference
\end{tabular}

$C D T$ carbohydrate-deficient transferrin, $N S$ non-significant

a $\% \mathrm{CDT}>2.15 \%$ indicates recent, regular high alcohol consumption 


\section{Discussion}

Valproate has been extensively used as a pharmaceutical drug for prevention of relapse in chronic alcohol addictive patients. The effectiveness of treatment with valproate was evaluated by measuring the values of \%CDT, which represents the desialylated isoforms induced by alcohol and has been adopted as the most sensitive marker for monitoring alcohol abuse [28].

The most commonly reported adverse effects of valproate include gastrointestinal disturbances, tremor and bodyweight gain. Other notable adverse effects include encephalopathy symptoms (sometimes associated with hyperammonemia), platelet disorders, pancreatitis and liver toxicity [7]. This study shows that a serum concentration of total VPA $>30 \mu \mathrm{g} / \mathrm{mL}$ is more effective in maintaining alcohol abstinence than a lower one. More interestingly, a total VPA serum level between 31 and $50 \mu \mathrm{g} / \mathrm{mL}$ shows the same effectiveness as a higher one. Therefore, a serum concentration ranging from 30 to $50 \mu \mathrm{g} / \mathrm{mL}$, lower than the accepted therapeutic range for epilepsy $(50-100 \mu \mathrm{g} / \mathrm{mL})$, could have the same effectiveness but with a lower risk of adverse effects. In fact, when we reported the \%CDT values among the four groups, we had evidence \%CDT levels were significantly low corresponding to a total VPA concentration between 31 and $50 \mu \mathrm{g} / \mathrm{mL}$ and $>50 \mu \mathrm{g} / \mathrm{mL}$. In addition, the number of relapses to alcohol addiction was lower in the groups with serum total VPA concentrations between 31 and $50 \mu \mathrm{g} / \mathrm{mL}$ or $>50 \mu \mathrm{g} / \mathrm{mL}$ ( 1 and 0 cases, respectively) compared with patients with mean serum total VPA concentrations $<10 \mu \mathrm{g} / \mathrm{mL}$ or between 10 and $30 \mu \mathrm{g} / \mathrm{mL}$ (six and five cases, respectively) and there are no statistically significant differences between the two groups with the highest serum total VPA levels.

Moreover, serum total VPA concentration but not $\% \mathrm{CDT}$ levels correlated with modulation of platelet counts; as a matter of fact, in patients with serum total VPA levels $>50 \mu \mathrm{g} / \mathrm{mL}$, we found lower platelet counts with respect to the other groups. This finding is quite relevant since adoption of a standardized lower VPA concentration (ranging $30-50 \mu \mathrm{g} / \mathrm{mL}$ ) may be sufficient to achieve the best therapeutic efficacy with a reduced risk of adverse effects.

It has been demonstrated that valproate is characterized by a hepatic metabolism and a pronounced inter-individual variability in the pharmacokinetics [30, 31]. This variability may be due to genetic polymorphisms that encode drug metabolizing enzymes as such cytochrome P450 2C9, 2C19 (CYP2C9, CYP2C19) and uridine diphosphate (UDP) glucuronosyltransferase (UGTs) involved in the hepatic metabolism of valproate. Thus, such polymorphisms, affecting the serum concentration of valproate, may influence the effectiveness of this drug in maintaining alcohol abstinence. Moreover, testing these genetic variants prior to initiating drug treatment may indicate the best valproate administration to patients considering the possibility of titrating the valproate dosage to achieve a serum total VPA level of between 31 and $50 \mu \mathrm{g} / \mathrm{mL}$ and could decrease the likelihood of side effects. Therefore, administering the appropriate dosage must be considered a key concept in the effort to optimize drug treatment.

\section{Conclusions}

Since we have demonstrated that the best therapeutic effectiveness of valproate on alcohol addictive patients correlates with serum concentration between 31 and $50 \mu \mathrm{g} /$ $\mathrm{mL}$, it would be of clinical interest to test CYPs/UGTs genetic profile of patients and to titrate the valproate dosage to achieve the indicated level for the best therapeutic performance.

\section{Compliance with Ethical Standards}

Ethical approval Informed consent was retrieved from patients whose retrospective data were used for this study. In addition, according to the guidelines of the Declaration of Helsinki for retrospective studies, we notified this project to the University Department where experiments were conducted and to the local Ethical Committee. However, internal procedures do not require an ethical committee formal approval.

Conflict of interest The following researchers do not declare any conflict of interests for the submitted paper: Dr. Vincenzo De Iuliis, Dr. Raimondo Gelormini, Dr. Mariarosaria Flacco, Dr. Giuseppe Moriello, Dr. Marika Caruso, Dr. Eugenia Barone, Dr. Maria Golato, Prof. Elena Toniato, Prof. Pio Conti, Prof. Stefano Martinotti.

Funding This project was partially funded $(60 \%)$ by Ateneo Grants from Ministero dell'Università, Italy to SM and ET. We also received partial contribution to research expenses by the Department of Medical, Oral and Biotechnologic Sciences, University of Chieti "G. d'Annunzio", Italy.

Open Access This article is distributed under the terms of the Creative Commons Attribution-NonCommercial 4.0 International License (http://creativecommons.org/licenses/by-nc/4.0/), which permits any noncommercial use, distribution, and reproduction in any medium, provided you give appropriate credit to the original author(s) and the source, provide a link to the Creative Commons license, and indicate if changes were made.

\section{References}

1. MacDonald RL, Kelly KM. Antiepileptic drug mechanisms of action. Epilepsia. 1995;36:S2-12.

2. Perucca E. Established antiepileptic drugs. Baillières Clin Neurol. 1996;5:693-722. 
3. İlik F, Pazarli AC, Dogan A. Prednisolone as an effective treatment for epilepsy. Eur J Inflamm. 2014;12:395-8.

4. Löscher W. Basic pharmacology of valproate: a review after 35 years of clinical use for the treatment of epilepsy. CNS Drugs. 2002;16:669-94.

5. Neuman MG, Shear NH, Jacobson-Brown PM, Katz GG, Neilson HK, Malkiewicz IM, Cameron RG, et al. CYP2E1 mediated modulation of valproic acid-induced hepatotoxicity. Clin Biochem. 2001;34(211-218):3.

6. Nicolson A, Leach JP. Future prospects for the drug treatment of epilepsy. CNS Drugs. 2001;15(955-968):4.

7. Perucca E. Pharmacological and therapeutic properties of valproate: a summary after 35 years of clinical experience. CNS Drugs. 2002;16:695-714.

8. Keck PE, McElroy SL, Friedman LM. Valproate and carbamazepine in the treatment of panic and behavioral dyscontrol syndromes. J Clin Psychopharmacol. 1992;12:36S-41S.

9. Viola J, Ditzler T, Batzer W, Harazin J, Adams D, Lettich L, Berigan T. Pharmacological management of post-traumatic stress disorder: clinical summary of a five-year retrospective study, 1990-1995. Mil Med. 1997;162:616-9.

10. Marseglia L, Manti S, D’Angelo G, Arrigo T, Cuppari C, Salpietro C, Gitto E. Potential use of melatonin in procedural anxiety and pain in children undergoing blood withdrawal. J Biol Regul Homeost Agents. 2015;29:509-14.

11. Zeise ML, Kasparow S, Zieglgansberger W. Valproate suppresses $\mathrm{N}$-methyl-D-aspartate-evoked, transient depolarizations in the rat neocortex in vitro. Brain Res. 1991;544:345-8.

12. Loescher W. Valproate induced changes in GABA metabolism at the subcellular level. Biochem Pharmacol. 1981;30:1364-6.

13. Maitre M, Ciesielski L, Cash C, Mandel P. Comparison of the structural characteristics of the 4-aminobutyrate:2-oxoglutarate transaminases from rat and human brain, and of their affinities for certain inhibitors. Biochimica et Biophysica Acta. 1978;522: 358-99.

14. Yoshino Y, Kohara K, Abe M, Ochi S, Mori Y, Yamashita K, Igase M, Tabara Y, Mori T, Miki T, Ueno S. Missense variants of the alanine: glyoxylate aminotransferase 2 gene correlated with carotid atherosclerosis in the Japanese population. J Biol Regul Homeost Agents. 2014;28:605-14.

15. van der Laan JW, de Boer T, Bruinvels J. Di-n-propylacetate and GABA degradation. Preferential inhibition of succinic semialdehyde dehydrogenase and indirect inhibition of GABAtransaminase. J Neurochem. 1979;32:1769-80.

16. Roy-Byrne PP, Ward NG, Donnelly PJ. Valproate in anxiety and withdrawal syndromes. J Clin Psychiatry. 1989;50(Suppl):44-8.

17. Nigro A, Nicastro A, Trodella R. Retrospective observational study to investigate Sinerga, a multifactorial nutritional product, and bacterial extracts in the prevention of recurrent respiratory infections in children. Int J Immunopathol Pharmacol. 2014;27: 455-60.

18. Rosenthal RN, Perkel C, Singh P, Anand O, Miner CR. A pilot open randomized trial of valproate and phenobarbital in the treatment of acute alcohol withdrawal. Am J Addict. 1998;7:198-204.

19. Hammer BA, Brady KT. Valproate treatment of alcohol withdrawal and mania. Am J Psychiatry. 1996;153:1232.

20. Brady KT, Sonne S, Lydiard RB. Valproate treatment of comorbid panic disorder and affective disorders in two alcoholic patients. J Clin Psychopharmacol. 1994;14:81-2.

21. Bertuccelli G, Marotta F, Zerbinati N, Cabeca A, He F, Jain S, Lorenzetti A, Yadav H, Milazzo M, Calabrese F, Tomella C, Catanzaro R. Iron supplementation in young iron-deficient females causes gastrointestinal redox imbalance: protective effect of a fermented nutraceutical. J Biol Regul Homeost Agents. 2014;28:53-63.

22. de Jong G, van Dijk JP, van Eijk HG. The biology of transferrin [Review]. Clin Chim Acta. 1990;190:1-46.

23. Stibler H. Carbohydrate-deficient transferrin in serum: a new marker of potentially harmful alcohol consumption reviewed. Clin Chem. 1991;37:2029-37.

24. Mollbrink A, Jawad R, Vlamis-Gardikas A, Edenvik P, Isaksson B, Danielsson O, Stål P, Fernandes AP. Expression of thioredoxins and glutaredoxins in human hepatocellular carcinoma: correlation to cell proliferation, tumor size and metabolic syndrome. Int J Immunopathol Pharmacol. 2014;27:169-83.

25. Helander A, Eriksson G, Stibler H, Jeppsson J-O. Interference of transferrin isoform types with carbohydrate-deficient transferrin quantification in the identification of alcohol abuse. Clin Chem. 2001;47:1225-33.

26. Stibler H, Borg S, Joustra M. Micro anion exchange chromatography of carbohydrate-deficient transferrin in serum in relation to alcohol consumption (Swedish Patent 8400587-5). Alcohol Clin Exp Res. 1986;10:535-44.

27. Meerkerk GJ, Njoo KH, Bongers IM, Trienekens P, van Oers JA. Comparing the diagnostic accuracy of carbohydrate-deficient transferrin, -glutamyltransferase, and mean cell volume in a general practice population. Alcohol Clin Exp Res. 1999;23: $1052-9$.

28. Legros FJ, Nuyens V, Minet E, Emonts P, Zouaoui Boudjeltia K, Courbe A, Ruelle J-L, Colicis J, de L'Escaille F, Henry J-P. Carbohydrate-deficient transferrin isoforms measured by capillary zone electrophoresis for detection of alcohol abuse. Clin Chem. 2002;48(12):2177-86.

29. Nunez DA, Schiaffino S, Roldán EJA. Comparison of two formulations of sodium divalproate plasma concentrations after a single $500 \mathrm{mg}$ oral dose in healthy subjects, and stochastic subanalysis of the individual "clinical perceptible" levels. J Bioequiv Availab. 2013;5:4. doi:10.4172/jbb.1000158.

30. Klotz U. The role of pharmacogenetics in the metabolism of antiepileptic drugs: pharmacokinetic and therapeutic implications. Clin Pharmacokinet. 2007;46:271-9.

31. Johannessen SI, Tomson T. General principles. Laboratory monitoring of antiepileptic drugs. In: Levy RM, Mattson RH, Meldrum BS, editors. Antiepileptic drugs. 5th ed. Philadelphia: Lippincott Williams \& Wilkins; 2002. p. 103-11. 